DOI:

Оксана Рогульська, кандидат педагогічних наук, доцент кафедри практики іноземної мови та методики викладання Хмельницького національного університету

\title{
МОДЕЛЬ СИСТЕМИ ПІДГОТОВКИ МАЙБУТНІХ УЧИТЕЛІВ ІНОЗЕМНОЇ МОВИ ДО ПРОФЕСІЙНОЇ ДІЯЛЬНОСТІ В УМОВАХ ІНФОРМАЦІЙНО-ОСВІТНЬОГО СЕРЕДОВИЩА ЗАКЛАДІВ ВИЩОЇ ОСВІТИ
}

У статті теоретично обтрунтовано модель системи підготовки майбутніх учителів іноземноїмови в умовах інформаційно-освітнього середовища закладів вищої освіти. Модель містить такі блоки: цільовий, теоретико-методологічний, змістово-технологічний, контрольно-результативний. Розроблена модель системи підготовки майбутніх учителів іноземної мови до професійної діяльності є ијілісною системою, всі структурні елементи якої мають власне функціональне призначення, впливають один на одного, перебувають у тісній взаємодії та спрямовані на досягнення заявленої мети.

Ключові слова: модель системи; підготовка майбутніх учителів іноземної мови; заклади вищої освіти, інформаиійно-освітнє середовище.

Jim. 9.

Oxana Rogulska, Ph.D.(Pedagogy), Associate Professor of the Foreign Language Practice and Teaching Methodology Department Khmelnytskiy National University

\section{SYSTEM MODEL OF THE FUTURE FOREIGN LANGUAGE TEACHERS’ TRAINING TO PROFESSIONAL ACTIVITY IN THE HIGHER EDUCATION INSTITUTIONS' INFORMATIONALAND EDUCATIONALENVIRONMENT}

The system model of the future foreign language teachers' training to professional activity in the higher education institutions' informational and educational environment is theoretically grounded in the article. The model contains the following blocks: target, theoretical and methodological, comprehensive and technological, monitoring and productive. The target block of the model reveals the purpose of professional training and social demand for a competitive future foreign language teachers. The target block of the model is a system-generating factor that develops other elements of the model necessary to achieve the expected result. The theoretical and methodological block comprises the main principles of the concept of the future foreign language teachers' training to professional activity; methodological approaches, general deictic and specific principles. The comprehensive and technological block contains the organizational and pedagogical conditions, the characteristics of the basic methods and forms of professional training, means and technologies for its implementation. The content provision of the model includes: academic disciplines belonging to the humanitarian and socio-economic, mathematical and scientific, professional and practical training cycles; disciplines from the cycles of free choice of educational institution, free student choice, various types of pedagogical practice aimed at the future foreign language teachers' training to professional activity. The system model of the future foreign language teachers' training to professional activity in the higher education institutions' informational and educational environment also represents the stages of its implementation: theoretical and practical, correction and stabilization, reflexive and recording. The control and result block determines the formation of components that ensure the readiness of the future foreign language teachers to professional activity: (motivational and valuable, cognitive and communicative, practical, professional and personal, evaluative-reflexive) criteria (motivational, knowledge, operational, personal, reflexive) and levels (low (reproductive), average (productive) or high (professional)).

Keywords: model of system; future foreign language teachers' training; higher education institutions, informational and educational environment.

П остановка проблеми. Україна, яка чітко обрала шлях на європейську інтеграцію, здійснює модернізацію освітньої діяльності в контексті європейських вимог. Наголос робиться на якості освіти i забезпеченні конкурентоспроможності випускників закладів вищої освіти та престижу української вищої освіти у світовому освітньому просторі.
Навчання іноземних мов визначається одним із пріоритетних напрямів реформування освіти, тому постає питання про підвищення рівня підготовки вчителів іноземної мови.

Аналіз останніх публікацій. На сучасному етапі розвитку педагогічної науки теоретичні аспекти професійної та методичної підготовки вчителя іноземної мови $є$ предметом дослідження 


\section{МОДЕЛЬСИСТЕМИПДГОТОВКИМАЙБУТНІХ УЧИТЕЛІВ ІНОЗЕМНОӤ МОВИ ДОПРОФЕСІЙНОӤ ДІЯЛЬНОСТІ В УМОВАХ ІНФОРМАЦИЙНО-ОСВІТНЬОГОСЕРЕДОВИЩА ЗАКЛАДІВ ВИЩОӤ ОСВІТИ}

багатьох науковців. Про це свідчать роботи конкретизувати вимоги суспільства до знань, В. Безлюдної, О. Бігіч, І. Бім, Т, Бочарникової, Н. Гальської, І. Зимньої, Г. Китайгородської, К. Кончович,Г.Крючкова, Р. Мартинової, С. Ніколаєвої, Д. Ольшанського,Ю.Пассова,В.Плахотніка,Т.Полонської, С. Роман, М. Сідун, В. Скалкіна, Н. Скляренко, М. Соловей, М. Тадеєвої, Я. Черньонкова тощо.

Невирішена раніше частина проблеми. Не зважаючи на значну кількість наукових праць, в яких представлено теоретичне обгрунтування моделей підготовки фахівців різних спеціальностей, теоретичне обгрунтування моделі системи підготовки майбутніх учителів іноземної мови до професійної діяльності в умовах інформаційно-освітнього середовища закладів вищої освіти не було предметом окремих наукових досліджень.

Мета статті - теоретично обгрунтувати модель системи підготовки майбутніх учителів іноземної мови до професійної діяльності в умовах інформаційно-освітнього середовища закладів вищої освіти.

Виклад основного матеріалу. Моделювання системи підготовки майбутнього учителя іноземної мови до професійної діяльності залежить від його головних характеристик. О. Артеменко зазначає, що сучасний педагог - вчитель іноземної мови - це професіонал, що отримав під час навчання загальнокультурну, фахову, психолого-педагогічну і методичну підготовку [5]. Результатом професійної підготовки майбутнього учителя традиційно вважають його готовність здійснювати професійну діяльність у вигляді здатності до використання новітніх форм, методів, прийомів, інноваційних технологій. В. Семиченко, зазначає, що педагог цієї галузі - це, насамперед, психолог, який допомагає дитині засобами комунікацій зорієнтуватися в соціально напруженій ситуації сьогодення, готує до вступу в соціум після закінчення школи, в його комунікативний простір [6].

Відтак під моделлю системи підготовки майбутніх учителів іноземної мови до професійної діяльності в умовах інформаційно-освітнього середовища розуміємо графічне відтворення спеціально організованої взаємодії науковопедагогічних працівників та студентів у процесі навчання у закладах вищої освіти. Модель системи підготовки майбутніх учителів іноземної мови до професійної діяльності допоможе у процесі дослідження розв'язати такі проблеми: сформулювати конкретну мету для викладачів $\mathrm{i}$ студентів, яку вони повинні досягти; здійснити контроль за ефективністю процесу підготовки вчителя іноземної мови до професійної діяльності; умінь, навичок і особистісних якостей майбутніх учителів іноземної мови та усвідомити студентами значення професійної діяльності в процесі їхнього професійного становлення; активізувати рефлексію студентів та їхню спрямованість на саморозвиток [9].

Моделювання і використання моделей органічно пов'язано із прогнозуванням. Але модель не лише забезпечує прогноз, а й робить його повнішим на підставі історичного досвіду, експертних оцінок, виявлених тенденцій на майбутне із урахуванням сучасних викликів [4]. Прогностичність моделі системи підготовки майбутніх учителів іноземної мови визначається: урахуванням не лише сучасних, але й майбутніх потреб суспільства, зокрема відображенням нових перспективних вимог до підготовки майбутнього учителя іноземної мови та тенденцій розвитку іншомовної професійної освіти; формулюванням методологічних положень моделі (основних загальнодидактичних та специфічних принципів організації професійної підготовки майбутніх учителів іноземної мови, наукових методологічних підходів тощо); урахуванням структури готовності майбутніх учителів іноземної мови; досягненням гнучкості й динамічності моделі за умов дотримання ступеневості та етапності підготовки майбутніх учителів іноземної мови до професійної діяльності; 3'ясуванням організаційно-педагогічних умов, що визначають методику та технології підготовки майбутніх учителів іноземної мови відповідно до структури готовності до здійснення професійної діяльності; відтворенням досягнення певного результату підготовки, який виражається у рівнях та передбачає постійний моніторинг; урахуванням динаміки змін не лише на рівні компонентів готовності до професійної діяльності майбутніх учителів іноземної мови, але й системи в цілому.

Ефективне функціонування моделі системи можливе, якщо вона відповідає вимогам щодо інших “учасників" процесу моделювання: інгерентність (щодо середовища, у якому вона існуе); достатня узгодженість 3 науковим середовищем, у якому вона функціонуватиме; простота (щодо суб'єкта, який створює або застосовує модель) - що простіша модель, то вона ближча до змодельованої реальності й зручніша для використання; адекватність (щодо об'єкта, який вона моделює) - повнота, точність й істинність моделі для реалізації поставленої цілі [7].

Розроблена модель системи підготовки майбутніх учителів іноземної мови до професійної 


\section{МОДЕЛЬСИСТЕМИПІДГОТОВКИМАЙБУТНІХ УЧИТЕЛІВ ІНОЗЕМНОӤ МОВИ ДОПРОФЕСІЙНОӤ ДІЯЛЬНОСТІ В УМОВАХ ІНФОРМАЦЙНО-ОСВІТНЬОГОСЕРЕДОВИЩАЗАКЛАДІВ ВИЩОӤ ОСВІТИ}

діяльності в закладах вищої освіти є цілісною системою, всі структурні елементи якої мають власне функціональне призначення, впливають один на одного, перебувають у тісній взаємодії і спрямовані на досягнення задекларованої мети.

Отже, модель системи підготовки містить такі блоки: ичільовий; теоретико-методологічний; змістово-технологічний; контрольнорезультативний.

Цільовий блок моделі визначає мету підготовки майбутніх учителів іноземної мови в умовах інформаційно-освітнього середовища закладів вищої освіти (формування й розвиток інноваційного світогляду, інноваційного стилю науково-педагогічного мислення, знань та умінь у сфері психолого-педагогічних, лінгвістичних і методичних наук; системи мови та основних лінгвістичних і лінгводидактичних категорій, механізмів мовлення, а також історії, культури, сучасних проблем країни, мова якої вивчається; особливостей усіх компонентів навчальновиховного процесу: цілей, методів, засобів тощо; психологічних особливостей учня, сфер його інтересів і схильностей, закономірностей оволодіння іноземною мовою в умовах школи, зокрема різноманітних умов, які існують сьогодні; змісту програми 3 навчання іноземних мов та інших директивних документів; основних положень дидактико-методичної концепції, на якій побудований зміст підручника, який він використовує у практиці власної педагогічної діяльності; основних вимог, які визначає суспільство до особистості сучасного вчителя, зокрема до рівня його професійної майстерності; здатності до навчання, виховання і розвитку інноваційної особистості учня, потреби у постійному розвитку особистісно професійних якостей, удосконаленні професійно-педагогічної діяльності; забезпечення високого рівня готовності до професійної діяльності) [1], та соціальне замовлення на конкурентоспроможного майбутнього викладача іноземної мови. Цільовий блок моделі $є$ системотвірним чинником, що продукує інші елементи моделі, необхідні для досягнення очікуваного результату.

Теоретико-методологічний блок охоплює основні положення концепції підготовки майбугніх викладачів іноземної мови до професійної діяльності; методологічні підходи (системний, компетентісний, аксіологічний, культурологічний, діяльнісний, комунікативний, центрований на студенті, міждисциплінарний); загальнодидактичні та специфічні принципи навчання (гуманізації та гуманітаризації; науковості; систематичності й послідовності; модульності; доступності і посильності; зв'язку теорії з практикою; індивідуалізації; моделювання професійної діяльності або функціональності; інноваційності; урахування міжпредметних зв'язків; соціокультурної спрямованості; свідомості, діяльності та самостійності; комунікативно-орієнтованого навчання). Теоретико-методологічний блок через основні положення концепції, визначення методологічних підходів та загально дидактичних і специфічних принципів підготовки майбутнього вчителя іноземної мови до професійної діяльності безпосередньо впливає на структуру і характер змістово-технологічного блоку моделі.

В змістово-технологічному блоиі представлено організаційно-педагогічні умови, характеристика основних методів, форм професійної підготовки, засобів та технологій. Організаційно-педагогічні умови підготовки майбутніх учителів іноземної мови до професійної діяльності такі:

1. Підвищення мотивації до професійної діяльності та формування професійних ціннісних орієнтацій у майбутніх учителів іноземної мови шляхом використання інтерактивних технологій.

2. Використання особистісно-орієнтованих технологій у професійній підготовці майбутніх учителів іноземної мови.

3. Впровадження різних видів практики та позааудиторної роботи для набуття досвіду майбутньої професійної діяльності.

4. Створення та підтримка освітньокреативного середовища для формування готовності майбутніх учителів до професійної діяльності.

5. Розвиток професійної рефлексії у майбутніх учителів іноземної мови.

Змістове забезпечення моделі регламентовано Законом України "Про вищу освіту", впровадження якого регулюється Державним стандартом вищої освіти, Галузевим стандартом вищої освіти, освітньо-професійними програмами, освітньо-кваліфікаційними характеристиками та навчальними планами підготовки фахівців за спеціальністю “014 Середня освіта. Англійська мова і література” освітньо-кваліфікаційних рівнів “бакалавр”, “магістр”. Шляхом аналізу навчальних планів факультетів, які здійснюють підготовку майбутніх учителів іноземної мови було виокремлено блок навчальних дисциплін, які прямо чи опосередковано впливають на підготовку майбутніх учителів іноземної мови до професійної діяльності.

Таким чином, у циклі гуманітарної та соціально-економічної підготовки ми виокремили такі дисципліни: “Історія України”, “Українська мова за професійним спрямуванням”, “Історія 


\section{МОДЕЛЬСИСТЕМИПІГОТОВКИМАЙБУТНІХ УЧИТЕЛІВ ІНОЗЕМНОӤ МОВИ ДОПРОФЕСЙНОӤ ДІЯЛЬНОСТІ В УМОВАХ ІНФОРМАЦЙНО-ОСВІТНЬОГОСЕРЕДОВИЩАЗАКЛАДІВ ВИЩОӤ ОСВІТИ}

Української культури”, “Філософія”. У циклі математичної та природничо-наукової підготовки майбутніх учителів іноземної мови було виокремлено: "Вступ до мовознавства", “Загальне мовознавство”, “Стилістику”, “Лексикологію”, “Теоретичну фонетику”, “Теоретичну граматику", "Історію мови” тощо. У циклі професійної та практичної підготовки “Загальну психологію”, “Вікову психологію”, “Історію педагогіки”, “Основи педагогічної майстерності”, "Педагогіку і психологію вищої школи”, “Дидактику”, “Теорію та методику виховання”, “Школознавство”, “Соціальну психологію”, “Практичний курс англійської мови”, “Практичний курс другої іноземної мови (німецької)”, “Практичну граматику німецької мови”, “Практичну фонетику”, “Практичну граматику англійської мови” тощо. Із циклу дисциплін вільного вибору навчальних закладів виокремлено такі дисципліни: “Сучасна українська літературна мова”, “Освітні технологіі”, “Методика виховної роботи в літніх оздоровчих закладах", “Новітні технології у навчанні іноземних мов”, “Теорія і практика перекладу”, “Теоретичний курс другої іноземної мови” тощо. Із циклу дисциплін вільного вибору студента "Новітні технології оцінювання в контексті особистісно-орієнтованого навчання", "Проектна методика навчання іноземної мови”, “Ділова англійська мова”, “Ділова німецька мова”, “Особливі випадки граматики сучасної німецької мови”, “Основи зіставного мовознавства”, “Лінгвістичний аналіз художнього тексту”, “Особливості словотворення німецьких дієслів”, “Порівняльна типологія”, “Лінгвокраїнознавство (німецька мова)", “Культура мовлення та ораторське мистецтво”, “Міжкультурна комунікація”, “Інтерпретація художнього тексту”, “Література Англії та США”, “Порівняльна професійна педагогіка”, “Сучасні лінгводискурсивні дослідження”, “Англомовне академічне письмо”, “Аналітичне читання (німецька мова)", "Культура наукової української мови” тощо.

Ще одним компонентом змістового забезпечення професійної підготовки майбутнього вчителя іноземної мови до професійної підготовки вважаємо різні види практик: педагогічну практику, педагогічну (асистентську) практику, педагогічну практику (навчальну), педагогічну практику (виробничу), педагогічну практику в літніх оздоровчих закладах (виробничу) [3].

Таким чином, змістове забезпечення моделі включає: навчальні дисципліни 3 циклу гуманітарної та соціально-економічної, математичної та природничо-наукової, професійної та практичної підготовки; дисципліни 3 циклу вільного вибору навчального закладу, та вільного вибору студента, різні види педагогічної практики, які спрямовані на професійну підготовку майбутніх учителів іноземної мови до професійної діяльності.

Методи, засоби, форми та технологї навчання, $є$ ще одним компонентом забезпечення моделі системи професійної підготовки майбутніх вчителів іноземної мови до професійної діяльності.

Наступним у моделі системи професійної підготовки майбутніх учителів іноземної мови до професійної діяльності в умовах інформаційноосвітнього середовища закладів вищої освіти є виокремлення етапів ї̈ реалізації [2]. Хочемо охарактеризувати кожен 3 них:

Теоретико-практичний етап передбачав опанування майбутніми учителями іноземної мови навчальних дисциплін із циклу гуманітарної та соціально-економічної, математичної та природничо-наукової, професійної та практичної підготовки; дисциплін із циклу вільного вибору навчального закладу, та вільного вибору студента. Саме на цьому етапі відбувався процес грунтовного закладання основ теоретичних знань, які будуть необхідні у подальшій професійній діяльності майбутніх учителів іноземної мови. Ознаками теоретико -практичного етапу є: чітке покликання майбутніх учителів іноземної мови до педагогічної діяльності; формування первинного інтересудо професії вчителя та свідомої установки щодо необхідності фахової підготовки. Тривалість вказаного етапу - I-II курси навчання. Даний етап був спрямований на активізацію пізнавальної діяльності та ціннісних орієнтацій студентів через проведення навчальних дискусій, мотиваційноцільових тренінгів, лабораторних і практичних робіт, дидактичних рольових та ділових ігор, проблемних лекцій, лекцій-бесід, лекцій-дискусій, застосування сучасних інноваційних та інтерактивних методів: методу проектів, методу ціннісного зіставлення, кейс-методу тощо [2].

Корекиійно-стабілізаційний етап передбачав продовження опанування і засвоєння студентами системи психологічних, педагогічних, лінгвістичних, методичних знань, фахових методик, сучасних інноваційних технологій навчання, дисциплін фахового спрямування; формування практичних умінь і навичок; формування позитивних мотивів, ціннісних орієнтацій, переконання в правильному виборі майбутньої професії, стимулювання пізнавальної активності і відповідальності у навчанні та майбутній професійній діяльності. На даному етапі тривав розвиток комунікативних умінь студентів, 


\section{МОДЕЛЬСИСТЕМИПІДГОТОВКИМАЙБУТНІХ УЧИТЕЛІВ ІНОЗЕМНОӤ МОВИ ДОПРОФЕСІЙНОӤ ДІЯЛЬНОСТІ В УМОВАХ ІНФОРМАЦЙНО-ОСВІТНЬОГОСЕРЕДОВИЩАЗАКЛАДІВ ВИЩОӤ ОСВІТИ}

професійно-особистісних якостей, педагогічних здібностей; формування професійно-орієнтованих переконань, установок та поглядів щодо подальшої педагогічної діяльності; здійснювався контроль, аналіз та оцінювання результатів навчання, перевірялися рівні засвоєння навчального матеріалу, рівні сформованості відповідних умінь і навичок. Студенти проходили навчальну та педагогічну практику й застосовували набуті теоретичні знання в практичній діяльності. Тривалість даного етапу - III-IV курси навчання [2]. На цьому етапі, як і на попередньому використовувалися нетрадиційні форми організації навчання. Студентам пропонувалися інтерактивні семінари, лекції, практичні заняття, дискусії 3 провокативними запитаннями, круглі столи, “мозковий штурм”, заняття-прес-конференції, заняття-подорожі, заняття-фантазії, заняттяекскурсії, рольові та ділові ігри, тренінги, вебквести, моделювалися ігрові ситуації спілкування, що імітували реальні умови професійної діяльності. Окрім переліченого вище, упровадження нетрадиційних форм організації навчання залучало студентів до науководослідницької діяльності.

Рефлексійно-закріплювальний етап моделі системи підготовки майбутніх учителів іноземної мови до професійної діяльності в умовах інформаційно-освітнього середовища закладів вищої освіти тривав протягом навчання в магістратурі. Цей етап характеризувався чіткою сформованістю системи лінгвістичних, психологічних, педагогічних та методичних знань про особливості перебігу сучасного процесу навчання, досконалим володінням іноземних мов, фаховими методиками та інноваційними технологіями навчання 3 їх свідомим використанням, високим рівнем професійної готовності до професійної педагогічної діяльності. При цьому особливе значення відводилося проходженню майбутніми учителями іноземної мови навчально-виробничої практики в реальних умовах професійної діяльності. Отже, для третього етапу підготовки майбутнього вчителя іноземної мови характерними були організація практики студентів, спрямованої на пошук творчого виконання професійних завдань; стимулювання креативного самовираження студентів; підготовка студентів до рефлексії результатів своєї професійної діяльності; актуалізація самостійного планування та проектування індивідуальної спрямованості на майбутню професійну самореалізацію [8].

Контрольно-результативний блок визначає сформованість компонентів, що забезпечують готовність майбутніх учителів іноземної мови до професійної діяльності: (мотиваційно-цуіннісного, когнітивно-комунікативного, діяльніснопрактичного, професійно-особистісного, оцінно-рефлексивного), критерії (мотиваційний, знаннєвий, операційний, особистісний, рефлексивний) і рівні (низький (репродуктивний), середній (продуктивний) чи високий (професійний).

Висновок. Використання методу моделювання дало можливість створити модель системи підготовки майбутніх учителів іноземної мови до професійної діяльності в умовах інформаційноосвітнього середовища закладів вищої освіти. Спроектована модель характеризується цілісністю, всі вказані блоки є взаємопов'язаними, мають певне змістове навантаження, працюють на кінцевий результат - позитивна динаміка готовності майбутніх учителів іноземної мови до професійної діяльності. Перспективами подальших розвідок вбачаємо обгрунтування організаційно-педагогічних умов підготовки майбутніх учителів іноземної мови до професійної діяльності в умовах інформаційно-освітнього середовища закладів вищої освіти.

\section{ЛІТЕРАТУРА}

1. Бойко Г. Формування професійної компетенції вчителів іноземних мов початкової школи [Електронний pecypc]. - Режим доступу: http://oldconf.neasmo.org.ua/ node $/ 3029$

2. Гарачук Т. В. Модель підготовки майбутнього вчителя початкової школи до роботи 3 математично здібними школярами [Електронний ресурс]. - Режим доступу: https://dspace.udpu.edu.ua/jspui/bitstream/ 6789/2750/1/model.doc

3. Липчанко-Ковачик Н. О. Підготовка майбутніх бакалаврів-філологів до використання інтерактивних технологій у професійній діяльності [Електронний pecypc]. - Режим доступу: http://ep3.nuwm.edu.ua/4031/

4. Почуєва О. О. Моделювання в теорії управління освітніми процесами [Електронний ресурс]. - Режим доступу: http://virtkafedra.ucoz.ua/el gurnal/pages/ vyp10/Pochueva.pdf

5. Пушкар Т. М. Формування готовності майбугніх учителів філологічних спеціальностей до міжособистісної взаємодії засобами комунікативних технологій [Електронний ресурс]. - Режим доступу : http://www.uk.x-pdf.ru/5pedagogika/ 2275363-11-udk-37839713-7-pravah-rukopisu-pushkar-tetyana-mikolaivnaformuvannya-gotovnosti-maybutnih-uchitelivfilologichni.php

6. Пушкар Т. М. Моделювання як теоретичний метод розробки педагогічної технології підготовки вчителів філологічного профілю. Підходи А.С. Макаренка до використання педагогічного моделювання [Електронний ресурс]. - Режим доступу: http://eprints.zu.edu.ua/11023/1/13ptmmyt.pdf 
7. Скрипник М. І. Підготовка науково-педагогічних кадрів, аспірантів та здобувачів: модернізація процесу навчання в системі післядипломної освіти: метод. рек. для сист. післядип. освіти / Марина Іванівна Скрипник; За наук. ред. Свгенії Родіонівни Чернишової; Держ. вищ. навч. закл. "Ун-т менедж. освіти". - К., 2014. - 151 с.

8. Тонконог Н. І. Формування індивідуальної стратегії освітньо-професійної діяльності у майбутніх учителів іноземних мов: дис. канд. пед. наук: $13.00 .04-$ теорія та методика професійної освіти / Наталія Іванівна Тонконог [Електронний ресурс]. - Режим доступу: http:/ /ephsheir.phdpu.edu.ua:8081/xmlui/handle/8989898989/ 2513? show $=$ full \&locale-attribute $=$ en

9. Шмирко О. С. Педагогічні умови професійного розвитку майбутніх вчителів іноземної мови у системі університетської педагогічної освіти: дис. канд. пед. наук: 13.00.04 - теорія та методика професійної освіти / Олена Сргіївна Шмирко [Електронний ресурс]. - Режим доступу: http://www.khnu.km.ua/root/res/2-25-47-10.pdf

\section{REFERENCES}

1. Boiko, H. Formuvannia profesiinoi kompetentsii vchyteliv inozemnykh movpochatkovoi shkoly [Formuvannia profesiinoi kompetentsii vchyteliv inozemnykh movpochatkovoi shkoly]. [Electronic resource]. Access mode: http://oldconf.neasmo.org.ua/

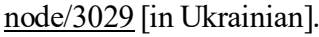

2. Harachuk, T. V. Model pidhotovky maibutnoho vchytelia pochatkovoi shkoly do roboty z matematychno zdibnymy shkoliaramy [Model of the future teacher of elementary school training to work with mathematically capable students]. [Electronic resource]. Access mode: https://dspace.udpu.edu.ua/jspui/bitstream/6789/2750/1/ model.doc [in Ukrainian].

3. Lypchanko-Kovachyk, N. O. Pidhotovka maibutnikh bakalavriv-filolohiv do vykorystannia interaktyvnykh tekhnolohii u profesiinii diialnosti [The future Bachelors in Philology training to the development of interactive technology in professional activity]. [Electronic resource]. Access mode: http://ep3.nuwm.edu.ua/4031/[in Ukrainian].

4. Pochuieva, O. O. Modeliuvannia v teorii upravlinnia osvitnimy protsesamy [Modeling in the theory of educational processes management]. [Electronic resource]. Access mode: http://virtkafedra.ucoz.ua/el gurnal/pages/ vyp10/Pochueva.pdf [in Ukrainian].
5. Pushkar, T. M. Formuvannia hotovnosti maibutnikh uchyteliv filolohichnykh spetsialnostei do mizhosobystisnoi vzaiemodii zasobamy komunikatyvnykh tekhnolohii [Formation of the future teachers of philological specialties readiness for interpersonal interaction by means of communication technologies]. [Electronic resource]. Access mode: http://www.uk.xpdf.ru/5pedagogika/ 2275363-11-udk-378-39713-7-pravahrukopisu-pushkar-tetyana-mikolaivna-formuvannyagotovnosti-maybutnih-uchiteliv-filologichni.php [in Ukrainian].

6. Pushkar, T. M. Modeliuvannia yak teoretychnyi metod rozrobky pedahohichnoi tekhnolohii pidhotovky vchyteliv filolohichnoho profiliu. Pidkhody A.S. Makarenka do vykorystannia pedahohichnoho modeliuvannia [Modeling as a Theoretical Method for the Development of Pedagogical Technology for the Training of Teachers of the Philological Profile. Makarenko's approaches to pedagogical modeling]. [Electronic resource]. Access mode: http://eprints.zu.edu.ua/11023/ 1/13ptmmyt.pdf [in Ukrainian].

7. Skrypnyk, M. I. (2014). Pidhotovka naukovopedahohichnykh kadriv, aspirantiv ta zdobuvachiv: modernizatsiia protsesu navchannia $v$ systemi pisliadyplomnoi osvity [Preparation of scientific and pedagogical staff, graduate students and applicants: modernization of the training process in the system of postgraduate education]. Kyiv: Education Management University, 151 p. [in Ukrainian].

8. Tonkonoh, N. I. Formuvannia indyvidualnoi stratehii osvitno-profesiinoi diialnosti u maibutnikh uchyteliv inozemnykh mov [Formation of an individual strategy of educational and professional activity for the future foreign languages teachers]. [Electronic resource]. Access mode: http://ephsheir.phdpu.edu.ua:8081/xmlui/handle/ $\underline{8989898989 / 2513 \text { ? show }=\text { full\&locale-attribute }=\text { en }[\text { in }}$ Ukrainian].

9. Shmyrko, O. S. Pedahohichni umovy profesiinoho rozvytku maibutnikh vchyteliv inozemnoi movy u systemi universytetskoi pedahohichnoi osvity [Pedagogical conditions of professional development of future foreign languages teachers in the system of university pedagogical education]. [Electronic resource]. Access mode: http://www.khnu.km.ua/root/res/2-25-47-10.pdf [in Ukrainian].

Стаття надійшла до редакції 17.10.2018

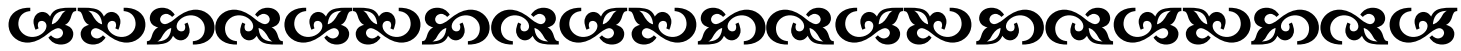

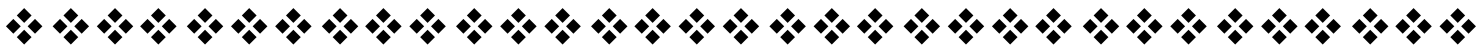

"В історії черпаємо ми мудрість; в поезї - дотепність; в математииі прониқливість; в природничих науқах - глибину; в моральної білособії - серйозність; в логіиі і риторииі-вміння сперечатися”.

Френсіс Бекон англійський вчений, боілософ

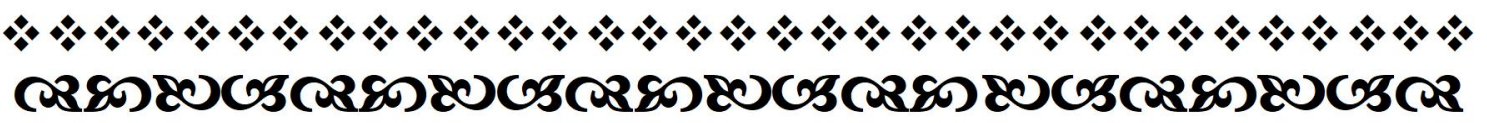

